p-ISSN 1693-1246

e-ISSN 2355-3812

January 2018
Jurnal Pendidikan Fisika Indonesia 14 (1) (2018) 18-25

DOI: 10.15294/jpfi.v14i1.9549

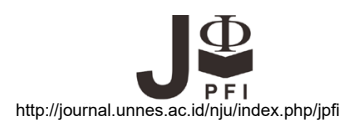

\title{
DEVELOPMENT OF GUIDED INQUIRY-BASED PHYSICS TEACHING MATERIALS TO INCREASE CRITICAL THINKING SKILLS OF HIGHSCHOOL STUDENTS
}

\author{
E. K. Nisa ${ }^{1 *}$, B. Jatmiko², T. Koestiari ${ }^{3}$ \\ ${ }^{1}$ Science Education Study Program, Postgraduate, Universitas Negeri Surabaya, Indonesia \\ ${ }^{2}$ Department of Physics Education, Faculty of Mathematics and Natural Sciences, \\ Universitas Negeri Surabaya, Indonesia \\ ${ }^{3}$ Department of Chemistry Education, Faculty of Mathematics and Natural Sciences, \\ Universitas Negeri Surabaya, Indonesia
}

Received: 31 July 2017. Accepted: 25 October 2017. Published: 1 January 2018

\begin{abstract}
This study aims to produce teaching materials based on inquiry physics to improve the critical thinking skills of high school students. This type of research is Research and Development and refers to the 4-D development model. This study was tested in class $X$. The results of this study obtained some findings include: 1) the validation of teaching materials obtained categories are very valid and reliable; 2) test legibility of physics teaching materials categorized high readability; and 3) N-gain improves students' critical thinking skills. Based on the results of this research, it can be concluded that the guided inquiry-based physics teaching materials worthy of use in learning and can improve the critical thinking skills of high school students.
\end{abstract}

\section{ABSTRAK}

Penelitian ini bertujuan untuk menghasilkan bahan ajar fisika berbasis inkuiri terbimbing untuk meningkatkan keterampilan berpikir kritis siswa SMA. Jenis penelitian ini adalah Research and Development dan mengacu pada model pengembangan 4-D. Penelitian ini diujicobakan di kelas X. Hasil penelitian ini diperoleh beberapa temuan diantaranya: 1) hasil validasi bahan ajar memperoleh kategori sangat valid dan reliabel; 2) uji keterbacaan bahan ajar fisika berkategori keterbacaan tinggi; 3) N-gain peningkatan keterampilan berpikir kritis siswa berkategori sedang. Berdasarkan hasil ujicoba ini dapat disimpulkan bahwa bahan ajar fisika berbasis inkuiri terbimbing layak digunakan dalam pembelajaran serta dapat meningkatkan keterampilan berpikir kritis siswa SMA.

(c) 2018 Jurusan Fisika FMIPA UNNES Semarang

Keywords: Critical Thinking Skills; Guided Inquiry; Physics Teaching Materials

\section{INTRODUCTION}

The development of the era of globalization as well as science and technology demands qualified human resources, one of them through an educational process. Education is a process that aims to influence learners to adapt to their social environment which resulting in a positive change in their habits so that enabling them to function well in society (Hamalik, 2013). Education is functioning to develop life

${ }^{*}$ Correspondence Address:

Jl. Ketintang No.30, Ketintang, Gayungan,

Surabaya, Jawa Timur 60231 Indonesia

E-mail: etikneizha27@gmail.com skills and to form a dignified nation character in order to educate the nation's generation. Therefore, the government is obliged to provide the best education system so that the potential of learners can be optimized and in the future they can become human resources that have good morality and honesty; intelligent, creative, and skilled in decision making, devotion to God; as well as become a democratic and responsible citizen (Sisdiknas, 2012).

One of the life skills need to be developed through the education process is critical thinking skills. In terms of Chance's critical thinking skills (1986), developing students' cri- 
tical thinking skills means training them to have the ability to analyze facts, find and organize ideas, defend opinions, make comparisons, draw conclusions, evaluate arguments and solve problems. According to Krulick \& Rudnick (1999), critical thinking is a way of thinking that tests, connects, and evaluates all aspects of a problem situation, including the ability to gather information, remember, analyze situations, read and understand and identify things required. Therefore, the process of critical thinking trained to students will shape their tendency to thoroughly consider a problem arising from experience so that they are able to make the right decisions. At the time of proceeding in the decision-making, it is seen that the process of scientific inquiry also occurs in students. Students will endeavor to develop the fact-finding process and relate it to the problems they experience as a basis of decision-making. Based on these definitions and facts, it appears that critical thinking is a well-organized mental process in the decision-making process to solve problems that can be trained through scientific inquiry activities.

In general, inquiry activities can be done in every subject, at any time by the teacher in the classroom, and to any student regardless of age. In this research, the subjects of the study are high school students who are considered essential to be familiarized in making important decisions for their future. They need to be trained to find the most important thing to do to solve the problem and find the most effective way to solve it. One of the intermediate media in trained critical thinking skills of high school students is the subject of physics. Physics is a part of science that plays an important role in improving the quality of life. Teaching physics not only trains the quality of thinking in analyzing natural phenomena logically and systematically but also how to apply them in everyday life. Critical thinking skills can be applied in the study of physics both in studying procedural knowledge so that the facts contained in each stage are easily understood, as well as conceptual knowledge that requires higher-order thinking to connect the facts so that the intended concept can be well conveyed (Arends, 2012). High school students who master critical thinking skills will be able to understand the factual knowledge that forms a conceptual knowledge and then apply it in everyday life. Conversely, when high school students face an important social phenomenon in society, they can respond appropriately and even contribute real and original thoughts. Therefore, it is important to design learning activities as well as to create a more conducive learning environment to guide students to learn by involving high order thinking skills so that critical thinking skills of high school students can be trained optimally.

Based on a preliminary study of students' critical thinking skills conducted in SMA Negeri 1 Tarik on sample 33 students of class $X$ on Hooke Law topic, it was found that critical thinking indicator which includes giving argument, induction, evaluating, and deciding an action is still low. This data concluded from the students who have not mastered the four aspects, namely to provide arguments of $72.73 \%$, induction of $84.85 \%$, evaluate $66.67 \%$ and decide an action of $90.91 \%$. While on the aspect of formulating the problem, the average student is good enough in mastering the aspect is reaching $63.64 \%$. Based on observation result, it is found that some causes have not been done maximally effort to trill critical thinking skill in physics study, they are: (1) physics subject teacher difficulty to handle student with low ability, so that active and motivated to learn physics; (2) students have difficulty using critical thinking ability because they are not used yet; (3) time limit of physics subject teachers to be able to provide teaching materials in training students' critical thinking skill; and (4) teaching materials used in the form of conventional teaching materials.

Based on the observation results it is obtained that the learning materials used can not guide students to find the concept of physics on their own. The results of research that examines similar problems indicate that to provide a direct learning experience that can help students to find the concept of physics on their own, then on the learning process, guided inquiry-based physics learning materials to support students' activities can be used. Teaching materials are a set of learning tools that contain learning materials, methods, limitations, and how to evaluate systematically designed and interesting in order to achieve the expected goal of achieving competence or subcompetence with all its complexity (Widodo and Jasmadi, 2008). Guided inquiry-based physics teaching materials are teaching materials containing scientific steps, ie orientation, formulating problems, formulating hypotheses, collecting data, testing hypotheses, and formulating conclusions. This is consistent with the opinion of Eggen (2012) that the learning model can provide opportunities for students and helping students gain an 
understanding of the scientific method to develop critical thinking skills, self-regulation, and understanding of specific topics is an inquiry learning model. In addition, Bilgin (2009) states that guided inquiry as a student-centered approach has an influence on students 'academic success and develops students' scientific process skills. Thus, teaching materials that can train critical thinking skills are teaching materials that contain the steps of guided inquiry learning model.

Steps of guided inquiry learning models contained in the teaching materials to give students the opportunity to train their critical thinking skills. Systematic of the teaching materials are designed to train students in formulating problems, giving arguments, inducing, evaluating, and determining an action (Wahyuni, 2015; Hermayani, Dwiastuti, and Marjono, 2015; Fauziah, 2014). In the learning process, inquiry learning model is a learning model that fosters students' ability to think and work scientifically and has a scientific attitude (Permendikbud No. 58, 2014). Guided inquiry learning is designed to train students' skills in conducting research and asking questions based on facts. Inquiry-based learning is guided in implementing five learning stages: 1) identifying a question or problem; 2) formulating the hypothesis; 3) collecting data; 4) test the hypothesis; and 5) formulate generalizations (Kardi, 2013). Learning activities using guided inquiry will familiarize students to actively seek information by conducting an experiment in solving a problem. Students will be accustomed to answering questions provided with accurate analysis so that will affect the achievement of maximum learning results.

The teaching materials are important in the learning process. The use of teaching materials will be easier for teachers in implementing the learning process and students will be more helpful and get ease in learning. Teaching materials can be made in various forms according to the needs and characteristics of teaching materials to be presented (Dharmasraya, 2008). Oktafiana (2015) argues that guided inquiry-based physics teaching materials on motion topic can improve students' creative thinking ability with an average creative gain gain of 0.69 . Similar research conducted by Wahyuni (2015) on the development of teaching materials of science, states that the science materials that developed it is feasible to be used in learning for junior high school because it scored $3.88,3.74$, and 3.70 of 4 scale from the results of expert validation. In addition, developed science teaching materials can also improve students' critical thinking skills.

Widodo and Jasmadi (2008) revealed that there are five characteristics of teaching materials: (1) self instructional, (2) self contained, (3) stand alone, (4) adaptive, and (5) user friendly. Teaching materials are said to be self instructional if they meet the following requirements: (a) There is a clear purpose; (b) Materials packaged into specific units; (c) There are examples and illustrations that support the clarity of the exposure of learning materials; (d) There are exercise questions, tasks or exercises; (e) Presented with a contextual approach; (f) Simple and communicative language; (g) Present a summary of instructional materials; (h) Provide self assessment based assessment instruments; (i) Instruments used by users to measure or evaluate the degree of mastery of the material; (j) Provide feedback on the assessment, so that its users know the level of mastery of the material, and (k) Available information on reference / enrichment that supports the intended learning materials. Self contained is a form of printed and written information deliberately presented for study by students containing all the materials or theory of lessons, and grouped in one page or one unit of competence and also accompanied by sub-competence. Stand alone teaching materials will be fulfilled if the teaching materials can survive alone, ie do not need help from other teaching materials. Good teaching materials already cover all the subject matter so it does not require other teaching materials to complete it. If the learner still uses and relies on other teaching materials other than the teaching materials used, the teaching materials are not categorized as stand-alone teaching materials. Adaptif good teaching materials not only can survive alone, but also can keep up with technology. It is said to be adaptive if the teaching materials can adapt the development of science and technology, flexible to use in various places, and the contents of learning materials and software can be used until a certain time. Good teaching materials, not only contain the source of science alone, but also created in a way higher quality. User friendly perfect teaching materials should be able to facilitate users when they want to use them. Every instruction and exposure of information will appears to be helpful and friendly with the wearer, including ease of user in responding, accessing as you wish. The use of simple language, 
easy to understand, and use of commonly used terms is one form of user friendly.

Based on the background and identification of the problem, the goal to be achieved in this research is to develop physics teaching materials that can improve the critical thinking skills of high school students.

\section{METHOD}

This research is Research and Development. The design of this study modifies the procedural model adapted from the development of 4D model devices ie define, design, development, and disseminate (Thiagarajan and Semmel, 1974). In this study the development stage will only be implemented in the defining, designing, and developing phases only. The depth stage is not implemented considering the limited time available in this research.

The subjects of this study are guided inquiry-based physics teaching materials on static fluid material developed and tested on 15 students in class X IPA 1 in SMAN 1 Tarik in Odd Semester Academic Year 2016/2017.

Data collection is done using validation sheet, legibility sheet, and test of critical thinking skill. To measure the feasibility of learning materials obtained by using the instrument validation sheet by two lecturers of Physics as expert testers. The effectiveness of the teaching materials was identified from the results of the reading material readability analyzed using the legibility test and improvement of students' critical thinking skills through pretest and posttest analyzed using $\mathrm{N}$-gain calculation.

The development procedure in this study was adapted from 4D development model according to Thiagarajan and Semmel. The steps taken in the development procedure with the 4-D model are as follows.

\section{Definition Stage}

This stage consists of five activities, namely: (1) needs analysis done as initial study about the need of development of teaching materials to improve the quality of learning which means also will be able to improve the quality of human resources in Indonesia. The development of students' competencies based on the need for future competence is the ability to communicate, think critically and creatively by considering the values and morals of Pancasila to become a democratic and responsible citizen, tolerant in diversity, able to live in a global society, have a broad interest in life and rea- diness to work, intelligence according to talent / interest, and care about the environment. The ability to think critically, creatively, and innovatively is needed to adjust to the development of science and technology; (2) student analysis is done to know the characteristic of student which include academic ability, background of knowledge, and level of cognitive development of student. Results of student analysis can be used as an overview to develop teaching materials; (3) task analysis is carried out by detailing the content of teaching materials in the form of an outline of main content that includes an understanding of the task in learning. This step is done by analyzing the basic competence and the indicator of critical thinking skills of the selected material that is static fluid; (4) concept analysis is conducted to identify the main concepts to be taught; systematically arranging; and detailing relevant concepts to form a concept map; (5) the formulation of learning objectives is based on core competencies and basic competencies in accordance with the 2013 curriculum.

\section{Design Stage}

The design stage is done to design the initial form of teaching materials for students. Teaching materials are student learning manuals used in learning activities. The teaching materials contain the lesson material that was adopted from several sources of physics textbooks.

\section{Development Stage}

The development stage is done to produce the revised teaching materials based on input from the experts. The results of the design are then developed with the steps (1) validation of teaching materials is useful to refine the initial design of learning materials, then ready for use by students. The teaching materials that have been made are then validated by two experts in the field of Physics education for advice and revision; (2) the readability test of the learning materials is used to assess the legibility of the revised teaching materials based on input from experts before being trialled on a broader subject; (3) limited trials are conducted to test the quality of teaching materials on selected subjects for the purposes of modification and effectiveness of teaching materials.

\section{RESULTS AND DISCUSSION}

This research development of physics 
teaching materials uses development procedures in accordance with 4-D development steps. The purpose of this development is to produce a guided inquiry-based physics teaching material on static fluid topic that is valid and effective.

\section{Define Stage}

At this stage, initial observations are made to identify the problem; facts in schools that serve as the basis for the development of physics teaching materials of static fluid subject matter; and data collection to determine the purpose of research through observation to the school that will serve as the research base. The next step is to formulate the problem related to the object to be studied. Problems identified in this analysis are: (1) the learning process that is still dominated by teachers and students only hears and records explanations from teachers; (2) the teachers never composed their own teaching materials. Teaching materials used in schools are purchased from publishers whose competency outcome indicators are often incompatible with indicators outlined in the lesson plans. At this stage, the formulation of static fluid indicators and learning objectives is based on concept and task analysis. These indicators were used to develop a set of students' critical thinking skills tests.

\section{Design Stage}

The developed teaching material aims to improve students' critical thinking skills. In the teaching materials contains a number of issues related to the concept of static fluid that occurs in everyday life. This teaching material also contains experimental procedures that are expected to assist students in trained their critical thinking skills. Systematic teaching materials include introduction, content, and cover. In the introduction section contains illustrations or images that are expected to bring up the problem especially the problems that often occur in everyday life.

Starting from the problems presented, students are expected to be able to analyze the problems by using the critical thinking skills they had before. The content section contains learning objectives, static fluid concepts, illustrations, examples that support concepts, conceptual linkages with science / technology, and activities that support the learning process. One of the learning support activities is an investigation activity in which there is a hypothetical section that provides an opportuni- ty for students to train critical thinking skills to construct hypotheses.

The content is made to facilitate the learning process in raising the ability that will be owned by students after reading the teaching materials. Teaching materials contain instructions to students, for example in answering practice questions; conducting practicum activities; including when observing the natural phenomena around them. Through contextual teaching materials, teachers can train students' critical thinking skills in formulating problems, giving arguments, and concluding inductively, even conducting evaluations to decide what to do in relation to the various cases given. Furthermore, the closing section contains the conclusions and references.

\section{Development Stage}

The preliminary step of the development stage is the expert validation that aims to assess the feasibility of the content of the teaching materials before being tested. Product improvements are made based on comments and suggestions from the validator, either in the form of written suggestions on the manuscript, comments on the validation sheet, or spoken suggestions obtained by discussing with experts related to the developed teaching materials. Validation activities are done by giving the script of the teaching materials and assessment instruments along with the validation sheet to the two expert validators.

The results of validation of teaching materials by two validators with a score range 1-4 are presented in Table 1.

Table 1. Expert Validation Results on Teaching Materials

\begin{tabular}{lccc}
\hline Contents & $\begin{array}{c}\text { Average } \\
\text { Score }\end{array}$ & Category & $\begin{array}{c}\text { Reliabil- } \\
\text { ity (\%) }\end{array}$ \\
\hline $\begin{array}{l}\text { Introduction } \\
\text { Contents }\end{array}$ & 3.50 & Valid & 100 \\
$\begin{array}{l}\text { Character- } \\
\text { istic }\end{array}$ & 3.55 & $\begin{array}{l}\text { Valid } \\
\text { Very }\end{array}$ & 96.1 \\
Closing & 4.00 & $\begin{array}{l}\text { valid } \\
\text { Very }\end{array}$ & 96.43 \\
Concept de- & 3.57 & Valid & 93.88 \\
velopment & & Very & 97.28 \\
Average & 3.65 & valid & \\
\hline
\end{tabular}

Table 1 shows that in general the results of validation of teaching materials developed 
have a very valid category with an average score of 3.65 and has an instrument reliability of $97.28 \%$ so that teaching materials can be used and reliable. The teaching material is valid if the score is above or equal to 2.6 and invalid is used if it scores below or equal to 2.5 (Ratumanan \& Laurens, 2006; Sudiarman, 2015).

Experimental materials that have been validated by experts are tested its legibility. Test legibility is done to support the results of feasibility of teaching materials by expert validators. Test results legibility of teaching materials can be seen in Figure 1.

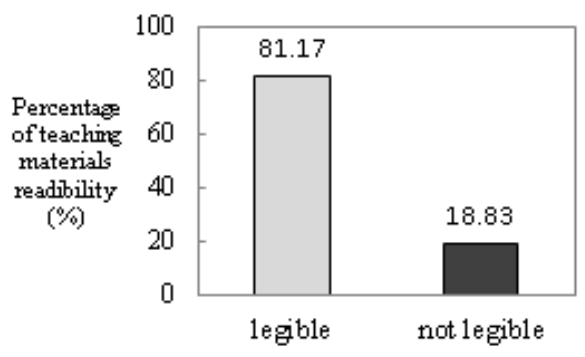

Figure 1. Result of Readability of Physics Teaching Material

Based on Figure 1, the results of the test of teaching material readability showed that the average score of 15 students' responses obtained that $81.17 \%$ of teaching materials can be read so that the teaching materials can be categorized high legibility. This means that teaching materials can be easily understood by students. In accordance with the regulation of the Ministry of National Education (2008) that one component of the material assessment is the linguistic aspect which includes the readability of the sentence; the clarity of information; the compliance with the Indonesian language rules in a good and correct way; and the utilization of language effectively and efficiently (clearly and briefly). Therefore it can be concluded that the developed physics learning materials have decent criteria to be used in learning.

In this study, the assessment is not only done on the feasibility of physics teaching materials but also on the effectiveness of teaching materials in improving students' critical thinking skills. Indicators of critical thinking skills used include: 1) formulating problems; 2) provide an argument; 3) conclude inductively; 4) conduct evaluation process; and 5) decide on an action (Ennis, 1995). Improving students' critical thinking skills is indicated from the pretest and posttest scores that have been adapted to the learning objectives as shown in Table 2.
Table 2 shows a significant increase in students' critical thinking skills classically identified a normalized gain score of 0.63 with moderate criteria. These results indicate that the teaching materials used give a significant influence in training students' critical thinking skills.

Table 2. Average Pretest and Posttest Scores

\begin{tabular}{lc}
\hline Data & Results \\
\hline Pretest Score & 46 \\
Posttest Score & 80 \\
N-Gain & 0.63 (moderate) \\
\hline
\end{tabular}

Table 3. Mean Scores of Critical Thinking Skills Indicators

\begin{tabular}{|c|c|c|c|c|}
\hline $\begin{array}{l}\text { Critical } \\
\text { Thinking } \\
\text { Indica- } \\
\text { tors }\end{array}$ & $\begin{array}{l}\text { Aver- } \\
\text { age } \\
\text { Score } \\
\text { of Pre- } \\
\text { test }\end{array}$ & $\begin{array}{c}\text { Average } \\
\text { Score } \\
\text { of Post- } \\
\text { test }\end{array}$ & $\begin{array}{l}\mathrm{N}- \\
\text { Gain }\end{array}$ & $\begin{array}{l}\text { Cate- } \\
\text { gories }\end{array}$ \\
\hline $\begin{array}{l}\text { Formu- } \\
\text { lating } \\
\text { problems }\end{array}$ & 4.73 & 7.13 & 0.74 & High \\
\hline $\begin{array}{l}\text { Giving } \\
\text { argu- } \\
\text { ments }\end{array}$ & 4.60 & 6.60 & 0.63 & $\begin{array}{l}\text { Mod- } \\
\text { erate }\end{array}$ \\
\hline $\begin{array}{l}\text { Con- } \\
\text { cluding } \\
\text { induc- } \\
\text { tively }\end{array}$ & 3.33 & 6.20 & 0.61 & $\begin{array}{l}\text { Mod- } \\
\text { erate }\end{array}$ \\
\hline $\begin{array}{l}\text { Con- } \\
\text { ducting } \\
\text { evalua- } \\
\text { tion }\end{array}$ & 2.93 & 5.7 & 0.5 & $\begin{array}{l}\text { Mod- } \\
\text { erate }\end{array}$ \\
\hline $\begin{array}{l}\text { Deciding } \\
\text { an action }\end{array}$ & 2.47 & 5.40 & 0.53 & $\begin{array}{l}\text { Mod- } \\
\text { erate }\end{array}$ \\
\hline
\end{tabular}

Improvement of critical thinking skills on each indicator is presented in Table 3 . The use of developed physics teaching materials has been able to train students in improving critical thinking skills. Five aspects of critical thinking are trained in the learning process, namely formulating problems, giving arguments, inductive conclusion, conducting the evaluation process, and deciding an action. Kholifah (2015) argues that individuals who have the skills of critical thinking will be able to decide and to think rationally based on some of the views they have on a different context. This means that critical thinking is needed by everyone to address a problem faced. Kholifah further claims that a 
critical thinker will be able to deduce from what he knows and know how to use information to solve problems, and seek sources of information relevant to him (Kholifah, 2015). From the test results and in line with the Kholifah opinion can be said that physics teaching materials that have been developed feasible use in learning and can improve students' critical thinking skills.

These results are consistent with the research of Kariawan, Sadia, and Pujii (2015) that the design of physics learning with the setting of inquiry learning model has met the valid, practical, and effective criteria for improving problem solving and critical thinking skills. In line with the results of the study, Antika, Sarwi, and Aji (2017) stated that guided inquiry learning with the help of student worksheets can improve the mastery of interpersonal skills and interpersonal skills of high school students. Ardi (2015) in his research reveals that physics-based instructional materials inquiry led to the subject matter of Temperature and Calor can improve student learning outcomes with the acquisition of $\mathrm{N}$-gain of 0.71 indicating a high increase of learning outcomes. Another supporting research is the result of Desmaria (2015) research which is that the instructional materials based on inquiry are guided on the material of Elasticity and Law of Hooke is declared effectively used in the learning with the acquisition of the average value of $\mathrm{N}$-gain of 0.69 in the medium category. The overall results of this study prove that the teaching materials that have been developed by each researcher has a significant influence on students 'thinking ability that is now evident from the results of this study also that the physics teaching materials that have been developed can improve students' critical thinking skills significantly.

\section{CONCLUSION}

Based on the results of the research and discussion, it can be concluded that the development of guided inquiry-based physics teaching materials is feasible to use in physics learning in high school. The result of validation of physics teaching materials got the average score of 3.65 with the category of very valid and the reliability of the instrument reaches the score of $92.28 \%$. It indicates that the teaching materials that have been developed can be used and reliable. The result of physics test readability test gets an average score of $81.17 \%$ with very high category. In addition, the physics teaching materials can also improve students' critical thinking skills as indicated by a $\mathrm{N}$-gain score of 0.63 in the medium category. Suggestions given include: 1) guided inquiry-based physics teaching materials in this study is limited to fluid topic only. For further development it is necessary to develop teaching materials on other subjects; 2) critical thinking skills in this study only trained for several meetings only. To practice students' critical thinking skills in their entirety, the implementation of instructional material development needs to be done on an ongoing basis for all subjects; and 3) guided inquiry-based physics teaching materials that developed in this research can be used by teachers as an alternative model to improve students' critical thinking skills.

\section{REFERENCES}

Antika, D. A., Sarwi, \& Aji, M. P. (2017). Pembelajaran Guided Inquiry Berbantuan Lembar Kerja Siswa untuk Meningkatkan Penguasaan Konsep dan Keterampilan Interpersonal Siswa SMA. Unnes Physics Education Journal, 6(1), 55-62

Ardi, A. (2015). Pengembangan Modul Pembelajaran Fisika Berbasis Inkuiri Terbimbing pada Materi Pokok Suhu dan Kalor. Jurnal Pembelajaran Fisika, 3(3), 65-69

Arends, R. (2012). Learning to Teach, 9th Edition. New York: Mc-Graw Hill.

Bilgin, I. (2009). The effects of guided inquiry instruction incorporating a cooperative learning approach on university students'achievement of acid and bases concepts and attitudetoward guided inquiry instruction. Scientific Research and Essay, 4(10), 1038-1046.

Carin \& Sund. (1998). Teaching Science Trough Discovery. Toronto: Merrll Publishing Company.

Chance, P. (1986). Thinking in the classroom: A survey of programs. New York: Teachers College, Columbia University.

Dharmasraya, P. (2008). Panduan Pengembangan Bahan Ajar. (Online), tersedia; http://penelitiantindakkelas.blogspot.com/2009/03/ripembelajaran-konstruktivis.html, diakses 30 Januari 2017.

Depdiknas. (2008). Panduan Pengembangan Bahan Ajar. Jakarta: Direktorat Jenderal Manajemen Pendidikan Dasar dan Menengah, Direktorat Pembinaan Sekolah Menengah Atas.

Depdiknas. (2009). Pembelajaran yang Megembangkan Critical Thinking. Jakarta: Direktorat Pembinaan SMA.

Desmaria. (2015). Pengembangan Modul Pembelajaran Fisika Berbasis Inkuiri Terbimbing pada Materi Elastisitas dan Hukum Hooke. Jurnal Pembelajaran Fisika, 3(1), 110-115. 
Eggen, P. D. (2012). Strategies for Teachers Teaching and Thinking Skills. Boston: Allyn and Bacon.

Ennis, R. H. (1995). Critical Thinking. New York: Prentice Hall.

Fauziah, E. N. (2014). Efektivitas Pembelajaran Model Inkuiri Terbimbing (Guided Inquiry) untuk Meningkatkan Penguasaan Konsep dan Keterampilan Berpikir IImiah pada Topik Kacamata dan Lup. Jurnal Pendidikan Fisika. $4(4), 1-10$

Hamalik, O. (2013). Kurikulum dan Pembelajaran. Jakarta: Bumi Aksara.

Hermayani, A. Z., Dwiastuti, S., \& Marjono. (2015). Peningkatan Motivasi Belajar dan Kemampuan Berpikir Kritis Siswa pada Materi Ekosistem melalui Penerapan Model Inkuiri Terbimbing. BIOEDUKASI Jurnal Pendidikan Biologi, 6(2), 79-85

Kardi. (2013). Model Pembelajaran Langsung Inkuiri Sains Teknologi dan Masyarakat. Surabaya: Universitas Negeri Surabaya.

Kariawan, I. G., Sadia, I. W., \& Pujani, N. M. (2015). Pengembangan Perangkat Pembelajaran Fisika dengan Setting Model Pembelajaran Inkuiri Untuk Meningkatkan Kemampuan Pemecahan Masalah dan Kemampuan Berpikir Kritis Siswa SMA. Jurnal Pendidikan dan Pembelajaran IPA Indonesia, 5(1), 1-11

Kholifah. (2015). Pengembangan Perangkat Pembelajaran Fisika Model Inkuiri dan Implementasinya untuk Melatihkan Keterampilan Berpikir Kritis Siswa SMA. Tesis. Surabaya: Pasca Sarjana Universitas Negeri Surabaya.

Krulick, S. \& Rudnick, J. A. (1999). Innovative Task to Improve Critical and Creative Thinking Skills. Developing Mathematical Reasoning in Grades K-12, 38-145.
Nurbaiti, N., Ertikanto, C., \& Wahyudi, I. (2014). Pengaruh Penggunaan Bahan Ajar Fisika Berbasis Inkuiri Terbimbing Terhadap Kemampuan Berpikir Kritis. Skripsi. Lampung: Pendidikan Fisika FKIP Universitas Lampung.

Oktafiana, S. (2015). Pengembangan Bahan Ajar Fisika Berbasis Guided Inquiry untuk Meningkatkan Berpikir Kreatif Siswa. Skripsi. Semarang: Jurusan Fisika FMIPA Universitas Negeri Semarang.

Peraturan Menteri Pendidikan dan Kebudayaan Republik Indonesia No. 58 Tahun 2014 tentang Kurikulum K13 SMP/MTs.

Ratumanan, G. T. \& Laurens. (2006). Evaluasi Hasil Belajar yang Relevan dengan Kurikulum Berbasis Kompetensi. Surabaya: Universitas Negeri Surabaya.

Sudiarman, Soegimin, \& Susantini, E. (2015). Pengembangan Perangkat Pembelajaran Fisika Berbasis Inkuiri Terbimbing untuk Melatihkan Keterampilan Proses Sains dan Meningkatkan Hasil Belajar pada Topik Suhu dan Perubahannya. Jurnal Pendidikan Sains, 4(2), 658-671.

Tim Redaksi Aulia. (2012). Sistem Pendidikan Nasional (SISDIKNAS). Bandung: Nuansa Aulia.

Thiagarajaan, S., Semmel, D. S. \& Semmel, M. I. (1974). Instructional Development for training teacher of Exceptional Children a Sourcebook. Bloomington: Center for Innovation on teaching the Handicaped.

Wahyuni, S. (2015). Pengembangan Bahan Ajar IPA untuk Meningkatkan Kemampuan Berpikir Kritis Siswa SMP. Jurnal Materi dan Pembelajaran Fisika, 5(2), 300-305.

Widodo, Chomsin, S. \& Jasmadi. (2008). Panduan Menyusun Bahan Ajar Berbasis Kompetensi. Jakarta: Gramedia 